\title{
SEJARAH KAMPUNG ANGKLUNG DI DESA PANYINGKIRAN KECAMATAN CIAMIS KABUPATEN CIAMIS TAHUN 1992-2020
}

\author{
Hilma Hanifa', Yat Rospia Brata², Agus Budiman ${ }^{3}$ \\ 1,2,3 Program Studi Pendidikan Sejarah, Universitas Galuh, Jl. R.E. Martadinata No, 150, Ciamis, Indonesia \\ email: hilmahaifa96@gmail.com¹, yatrospiabrata@gmail.com², abuy.agus.budiman@gmail.com³
}

\begin{abstract}
This research is motivated by public interest in the art of angklung which has shifted its function from an art to a performance that is entertainment. Angklung village is a community that produces and develops angklung in the Ciamis area. The purpose of this study was to determine the history of the establishment of the angklung village and the development of the angklung village in Panyingkiran Village, Ciamis District, Ciamis Regency. The method used is the historical/historical method (heuristics, criticism, interpretation and historiography) with a qualitative approach. Data collection techniques using observation techniques, interview techniques and documentation techniques. The results showed that: The history of the establishment of Angklung Village began with the emergence of angklung production in the 1990s when a resident named Alimudin intended to make and sell angklung. Over time, the business grew. Over time, his angklung began to be ogled by the domestic market until orders began to increase. The periodization of the development of angklung from 1992 to 2000 began with the migration of Mumu Alimudin from the Banjar area to Ciamis. Initially in 1992-2000 Kampung Angklung had the name Sanggar Angklung Panji Mekar. Alimudin's dream was realized in 2014 by being recognized as Kampung Angklung Panyingkiran after submitting it to the Ciamis Regency Government with great struggle. Angklung Panyingkiran village which is growing, there is a discourse by the local government to propose Nempel Village to be one of the educational tourism destinations that is framed by the nuances of traditional art.
\end{abstract}

Keywords: Angklung village, Angklung Village Development

\begin{abstract}
ABSTRAK
Penelitian ini dilatarbelakangi oleh minat masyarakat terhadap kesenian angklung yang mengalami pergeseran fungsi dari sebuah kesenian menjadi sebuah pertunjukkan yang bersifat hiburan. Kampung angklung merupakan sebuah komunitas yang memproduksi dan mengembangkan angklung di wilayah Ciamis. Tujuan penelitian ini untuk mengetahui sejarah berdirinya kampung angklung dan perkembangan kampung angklung di Desa Panyingkiran Kecamatan Ciamis Kabupaten Ciamis. Metode yang digunakan adalah metode sejarah/historis (heuristik, kritk, interpretasi dan historiografi) dengan pendekatan kualitatif. Teknik pengumpulan data menggunakan teknik observasi, teknik wawancara dan teknik dokumentasi. Hasil penelitian menunjukkan bahwa: Sejarah berdirinya Kampung Angklung berawal dari kemunculan produksi angklung sekitar tahun 1990-an tatkala seorang warga bernama Alimudin berniat untuk membuat dan menjual angklung. Lama kelamaan, usahanya tersebut berkembang. Seiring waktu, angklung buatannya mulai dilirik pasar domestik sampai pesanan pun mulai meningkat. Periodisasi perkembangan angklung 1992-2000 diawali dengan hijrahnya Mumu Alimudin dari daerah Banjar ke Ciamis. Awalnya pada tahun 1992-2000 Kampung Angklung memiliki nama Sanggar Angklung Panji Mekar. Impian Alimudin terwujud pada 2014 dengan diakui menjadi Kampung Angklung Panyingkiran setelah mengajukan kepada Pemkab Ciamis dengan penuh perjuangan. Kampung Angklung Panyingkiran yang semakin berkembang, ada wacana oleh pemerintah setempat untuk mengajukan Kampung Nempel menjadi salah satu tujuan wisata edukasi yang dibingkai oleh nuansa seni tradisi.
\end{abstract}

Kata kunci : Kampung Angklung, Perkembangan Kampung Angklung

Cara sitasi: Hanifa, H., Brata, Y. R., \& Budiman, A. (2021). Sejarah Kampung Angklung Di Desa Panyingkiran Kecamatan Ciamis Kabupaten Ciamis Tahun 1992-2020. J-KIP (Jurnal Keguruan dan IImu Pendidikan), 2 (3), 33-42. 


\section{PENDAHULUAN}

Kebudayaan merupakan sebuah karya atau hasil cipta rasa dan karsa suatu kelompok manusia. Bentuk hasil cipta atau usaha manusia tersebut adalah mengubah dan membuat sebuah susunan baru yang disesuaikan dengan kebutuhan rohani maupun jasmaninya. Karya masyarakat menghasilkan teknologi dan kebendaan atau kebudayaan jasmaniah yang diperlukan oleh manusia untuk alam sekitarnya agar kekuatan serta hasilnya dapat di abadikan bagi keperluan masyarakat (Ranjabar, 2006). Kebudayaan sangat erat kaitannya dan tidak dapat dipisahkan dari masyarakat terutama tentang pemikiran/ideals, benda hasil pemikiran/artifact, dan aktivitas/activities dalam kehidupan bermasyarakat. Dengan demikian maka dapat dikatakan bahwa kebudayaan sangat berperan penting dalam kelangsungan hidup masyarakat itu sendiri. Selain itu, kebudayaan sangat mempengaruhi pola kehidupan dan kelangsungan hidup dari suatu masyarakat. Keaslian kebudayaan tidak bisa ditebak karena kebudayaan adalah suatu hal yang abstrak dan bebas. Abstrak karena bentuknya yang tidak jelas, mengikuti pola hidup dari masyarakat itu sendiri dan bebas karena kebudayaan tidak terikat dengan suatu hal tetapi kebudayaan dapat berubah sewaktuwaktu mengikuti perubahan yang ada di masyarakat (Koentjaraningrat, 2000).

Salah satu unsur kebudayaan yang mengalami perkembangan dari masa ke masa adalah kesenian. Kesenian yang ada di tiap daerah akan berbeda satu dengan yang lainnya. Beberapa hal yang mempengaruhi ciri khas kesenian masing-masing daerah tentunya berkaitan dengan lingkungan geografis, pola interaksi masyarakat, hubungan dengan masyarakat lain, dan juga kepercayaan yang diyakini masyarakat tersebut. Pola interaksi terjadi ketika seseorang berusaha berkomunikasi dengan orang-orang yang berbeda budaya dan menyesuaikan perbedaanperbedaannya, hal ini membuktikan bahwa budaya itu dipelajari. Termasuk kesenian, adat dan kebiasaan-kebiasaan yang dilakukan sekumpulan anggota masyarakat (Widyasari, 2018).

Perhatian ahli antropologi mengenai seni bermula dari penelitian etnografi mengenai aktivitas kesenian suatu masyarakat tradisional. Deskripsi yang dikumpulkan dalam penelitian tersebut berisi mengenai benda-benda atau artefak yang memuat unsur seni, seperti patung, ukiran, dan hiasan. Penulisan tentang unsur seni pada kebudayaan manusia lebih mengarah pada teknikteknik dan proses pembuatan benda seni tersebut. Selain itu, deskripsi awal meneliti perkembangan seni musik, seni tari, dan seni drama dalam suatu masyarakat (Ranjabar, 2006). Setiap gejala, peristiwa, dan benda-benda apapun yang ada disekeliling kehidupan manusia bisa diolah menjadi sebuah karya seni. Daya kreativitas tersebut mampu menyulap kejadian dan benda yang dalam kehidupan keseharian dipandang biasa saja menjadi sesuatu yang bernilai seni (Rosyadi, 2012).

Salah satu bentuk kebudayaan dalam bidang seni dan tradisi pada masyarakat Sunda ialah kesenian angklung yang masih eksis hingga saat ini. Hal ini tidak terlepas dari semakin banyaknya terekspose setelah adanya bukti-bukti baik yang berupa artefak maupun yang tertulis (Brata \& Wijayanti, 2020). Angklung berkembang dimasyarakat Jawa Barat (Sunda) yang berbudaya agraris tradisional, orang Sunda menamakanya dengan "ngahuma" (Budi, 2001). Fungsi angklung dalam tradisi masyarakat sunda selalu dikaitkan dengan upacara ritual yang ditujukan kepada Dewi Sri atau dewi kesuburan atau penghormatan kepada Dewi Sri yang merupakan bentuk kepercayaan masyarakat Sunda kuno, dan masih terjaga hinggga kini. Karena sebagian besar masyarakat Sunda kuno pada waktu itu menganut aliran kepercayaan Sunda Wiwitan (agama sunda).

Selain itu, fungsi angklung dalam upacara ritual tersebut bertujuan untuk menjaga kelestarian hutan dari tangan-tangan jahil manusia yang tidak bertanggung jawab. Dari aturan yang telah dibuat, dengan demikian maka lahirlah suatu nilai kearifan lokal yang sangat penting untuk diteladani dan diterapkan oleh generasi penerus bangsa (Ratih \& Suryana, 2020). Hal ini menandakan bahwa masyarakat Sunda dalam segi kehidupan kesehariannya sederhana dan lebih memilih menyatu serta selaras dengan alam. Mereka lebih bijak dalam memanfaatkan segala sumber daya yang di berikan oleh alam ini, terlihat dari berbagai macam bangunan, pekakas, dan alat seni yang kebanyakan berbahan kayu serta bambu. Salah satu alat seni musik khas Sunda ialah angklung yang semuanya berbahan bambu. 
Angklung tersebar diseluruh wilayah di Jawa Barat dengan nama dan cara penyajian yang berbeda. Wujud angklung dimasyarakat Sunda tersebar diantaranya Angklung Baduy (Kanekes), Angklung Gubrag (Cipining-Bogor), Angklung Buncis (Arjasari Banjaran-Bandung), Angklung Dogdog Lojor (Ciptarasa-Sukabumi) dan Angklung Badeng (Sanding-Garut) (Soepandi, 1975). Kelima kesenian ini memiliki keunikan dan ciri khasnya tersendiri. Namun seiring dengan perkembangan zaman membuat alat ini telah mengalami perubahan. Hal ini turut berdampak pada pergeseran fungsi kesenian angklung yang dahulu memiliki nilai sakral dalam pelaksanaan prosesi ritual atau upacara. Kini menjadi alat seni pertunjukan yang sifatnya hiburan. Angklung saat ini biasanya dimainkan dalam pertunjukan teater, orkestra, acara khitanan, perkawinan, dan arakarakan. Meskipun demikian, masih ada beberapa daerah yang mempertahankan fungsi angklung seperti dahulu (Kusmaya, 2014). Salah satu solusi yang perlu ditempuh adalah dengan meningkatkan kompetensi SDM yang dimiliki suatu Negara termasuk Indonesia melalui peningkatan kualitas pendidikan dan pelatihan yang tepat (Pajriah, 2018). Selain itu, dengan mengajarkan siswa terhadap kesenian lokal diharapkan siswa mampu mengenal kesenian-kesenian daerah yang termasuk kedalam sejarah lokal dan siswa dapat memahami sejarah lokal tersebut sebagai pengetahuan (Sriningsih, Soedarmo \& Kusmayadi, 2021).

Selayaknya generasi-generasi saat ini harus senantiasa "ngamumule" (memelihara) baikbaik warisan leluhurnya. Di Jawa Barat sendiri walaupun tersebar, intensitas penggunaan ataupun produksi angklung. Saat ini hanya ada beberapa sentra pembuatan angklung di wilayah Provinsi Jawa Barat. Setelah kota Bandung yang terkenal dengan Saung Angklung Udjo yang tersohor hingga ke mancanegara. Kini pandangan beralih ke Kabupaten Ciamis tepatnya di Kampung Nempel RT 02/07 Desa Panyingkiran, Kecamatan Ciamis yang saat ini mulai menonjolkan eksistensinya dalam memproduksi angklung. Dilokasi tersebut setidaknya ada sekitar 40 kepala keluarga yang berperan aktif dalam pembuatan alat tersebut sehingga banyak orang yang mengistilahkannya dengan sebutan Kampung Angklung. Awal mula kemunculan produksi Angklung di desa Panyingkiran ini sekitar tahun 1990-an dan sampai saat ini masih berjalan serta berkembang (https://Kebudayaan.kemendikbud.go.id/bpnbjabar/kampung-angklung-di-kabupaten-ciamis/diakses pada 6-12-2020).

Berdasarkan pemaparan tersebut perlu kiranya dilakukan penelitian terkait Sejarah berdirinya Kampung Angklung dan Perkembangan Kampung Angklung di Desa Panyingkiran Kecamatan Ciamis. Tujuan dari penelitian ini yaitu untuk mengetahui sejarah berdirinya kampung angklung di Desa Panyingkirn Kecamatan Ciamis dan mengetahui perkembangan Kampung Angklung di Desa Panyingkiran Kecamatan Ciamis.

\section{METODE PENELITIAN}

Metode penelitian yang digunakan dalam penelitian ini adalah metode sejarah dengan pendekatan kualitatif yakni seperangkat aturan dan prinsip yang sistematis untuk mengumpulkan sumber-sumber sejarah secara efektif, menilainya secara kritis dan menyajikan sintesis dari hasilhasil yang dicapai dalam bentuk tertulis mengenai rekaman dan peninggalan masa lampau (Kuntowijoyo, 1995). Sebagai upaya memahami fenomena tentang apa yang dialami oleh subjek penelitian berdasarkan misalnya perilaku, persepsi, motovasi, tindakan dan lain-lain secara holistic dengan cara deskripsi, pada suatu konteks khusus yang alamiah dan manfaatkan berbagai metode ilmiah (Moelong, 2011). Selain itu, metode sejarah merupakan rekontruksi imajinatif tentang gambaran masa lampau peristiwa-peristiwa sejarah secara kritis dan analisis berdasarkan buktibukti dan data peninggalan masa lampau (sumber sejarah) (Ismaun, 2005). Selanjutnya menguji hipotesis yang berhubungan dengan penyebab, pengaruh atau perkembangan kejadian yang mungkin membantu dengan memberikan informasi pada kejadian sekarang dan mengantisipasi kejadian yang akan datang (Ismaun, 2005).

Adapun langkah penting atau teknik dalam metode sejarah adalah: (a) Heuristik atau mengumpulkan sebanyak-banyaknya sumber untuk dijadikan bahan-bahan penelitian (Gottschalk, 
1975; Kuntowijoyo, 1995); (b) Kritik atau verifikasi sumber berupa pengujian mengenai kebenaran atau ketepatan (akurasi) dari sumber itu. Kritik dilakukan melalui 2 tahap yaitu; kritik eksternal atau mengecek orientasi dan keaslian sumber melalui verifiasi atau pengujian terhadap aspek-aspek "luar" dari sumber sejarah, dan kritik internal, untuk mengecek kredibilitas sumber (Sjamsuddin, 2007). Digunakan untuk menguji keaslian suatu sumber atau mencari arti sebenarnya dari kesaksian yang diberikan narasumber, dan kredibilitas kesaksian dari narasumber, dalam hal ini menyangkut nilai moralitas dan kejujuran dari narasumber; (c) interpretasi atau penafsiran yang sering disebut sebagai bidang subjektifitas. Itu sebagian benar dan sebagian salah, benar karena tanpa penafsiran sejarawan, data tidak bisa berbicara (Kuntowijoyo, 1995); dan (d) historiografi yang menuntut daya kritis serta analisis kuat hingga akhirnya menghasilkan sintesis dari keseluruhan penelitian yang nantinya akan ia tuliskan dan menjadi sesuatu tulisan yang utuh dari penelitiannya (Sjamsuddin, 2007).

Teknik pengumpulan data yang digunakan yaitu; (a) Studi literatur, yaitu mengkaji dan menelaah secara mendalam buku-buku, arsip, skripsi, dan jurnal sebagai sumber berkaitan tentang Sejarah kampung angklung dan perkembangannya. Kegiatan pencarian sumber dilaksanakan di perpustakaan, arsip-arsip desa setempat, dan sumber internet; (b) wawancara bertujuan mengumpulkan data dalam menemukan permasalahan yang diteliti, dan mengetahui hal-hal lebih mendalam; (c) Observasi digunakan sebagai upaya memperoleh data informasi yang menjadi objek penelitian di lapangan. Hal ini sangat penting terutama sebagai bukti objektif atau empiris dari fenomena yang menjadi pokok permasalahan dalam penelitian ini (Sugiyono, 2015). Dengan melakukan observasi ini, penulis menjadi lebih memahami tentang subyek dan obyek yang sedang diteliti; dan (d) Dokumentasi berupa pengumpulan data yang berbentuk gambar lokasi, tulisan, atau karya-karya monumental seseorang, catatan harian, sejarah kehidupan, biografi, peraturan, kebijakan, foto, gambar hidup dan lain-lain yang menunjang penelitian (Sugiyono, 2015).

Untuk wawancara mengambil sumber dan narasumber, diantaranya: Bapak Dhea (58 tahun) sebagai Ketua Kesenian; Bapak Alimudin (54 tahun) sebagai Ketua Kampung Angklung; Bapak Ikin (45 tahun) sebagai Ketua Pengrajin; Bapak Sarip, S.Pd (47 tahun) sebagai Sekretaris Kelembagaan Masyarakat Yayasan Kampung Angklung; dan Ibu Hj Mimi (58 tahun) sebagai Tokoh Masyarakat Kampung Angklung.

\section{HASIL PENELITIAN DAN PEMBAHASAN}

\section{Sejarah Berdirinya Kampung Angklung di Desa Panyingkiran Kecamatan Ciamis}

Angklung merupakan salah satu alat musik tradisional masyarakat Sunda. Wilayah persebaran alat musik ini hampir ada di seluruh wilayah kabupaten/kota di Provinsi Jawa Barat. Walaupun tersebar, intensitas penggunaan ataupun produksi angklung berbeda-beda. Saat ini hanya ada beberapa sentra pembuatan angklung yang ada di Provinsi Jawa Barat. Setelah Kota Bandung yang terkenal dengan Saung Angklung Udjo yang sudah terkenal hingga ke mancanegara, lokasi lain yang hingga saat ini masih aktif memproduksi dan menjual angklung ada di Kampung Nempel RT 02/07 Desa Panyingkiran, Kecamatan Ciamis. Di lokasi tersebut setidaknya ada sekitar 40 Kepala Keluarga yang berperan aktif dalam membuat angklung sehingga banyak orang yang mengistilahkan lokasi tersebut sebagai Kampung Angklung Panyingkiran (Wawancara dengan Alimudin Ketua Adat, tanggal 09 maret 2021).

Awal kemunculan produksi angklung di Panyingkiran sekitar 1990-an tatkala Alimudin yang akrab disapa Mumu Angklung berniat membuat dan menjual angklung. Lama kelamaan, usahanya berkembang. Kemudian ia mulai merekrut pekerja tambahan yang tidak lain adalah tetangganya sendiri. Berkat kiprahnya angklung mulai terkenal dan tersohor. Berangkat dari pengalamannya sebagai buruh pembuatan angklung di daerah Banjar pada 1975 hingga setelah lulus STM pada 1986, Mumu mulai menguasai pembuatan sampai penyesuaian nada angklung (Wawancara dengan Alimudin Ketua Adat, tanggal 09 maret 2021). Kemudian beliau hijrah ke Ciamis tahun 1992, tepatnya di Desa Panyingkiran. Dengan melimpahnya bahan baku bambu di daerah Ciamis, la pun 
mulai merintis usaha produksi angklung skala kecil. Seiring waktu, angklung buatannya mulai dilirik pasar domestik sampai pesanan pun mulai meningkat. Dari sana akhirnya Alimudin mengajak masyarakat setempat untuk ikut bersama-sama memproduksi angklung, sehingga pesanan bisa terpenuhi. Dari 1992 sampai 2000 Kampung Angklung ini bernama Sanggar Angklung Panji Mekar. Penamaan ini disesuaikan dengan nama Karang Taruna Panyingkiran yaitu Panji Mekar.

Menurut Alimudin Ketua Adat Kampung Angklung (2021) bahwa, "Bagi saya memberikan ilmu yang bermanfaat bagi orang banyak itu berdampak baik. Terbukti sampai sekarang saya tidak kekurangan order, malah terus bertambah". Hasil binaan Mumu sudah melahirkan sekitar 100 lebih pengrajin angklung. Pada 2010 sampai sekarang, usaha ini pun menjadi mayoritas mata pencaharian masyarakat di kampung tersebut (Wawancara dengan Alimudin Ketua Adat, tanggal 09 maret 2021).

Sanggar Angklung Panji Mekar seiring berjalannya waktu, karena masyarakat mengaitkan Sanggar Angklung Panji Mekar dengan Saung Angklung Udjo serta dengan meningkatnya pesanan angklung, maka ia berinisiatif untuk mengubah namanya menjadi Kampung Angklung Panyingkiran di tahun 2014 dan cita-citanya terwujud dengan diakuinya penamaan menjadi Kampung Angklung Panyingkiran setelah mengajukan kepada Pemkab Ciamis dengan penuh perjuangan. Bahkan di 2016, Alimudin mendapat penghargaan dari Gubernur Jawa Barat Ahmad Heryawan sebagai pelopor pemberdayaan masyarakat.

\section{Perkembangan Kampung Angklung di Desa Panyingkiran Kecamatan Ciamis}

Perkembangan Kampung Angklung Panyingkiran setelah 2014-2021 sangat cepat, pertama nama Kampung Angklung mulai banyak dikenal, kedua dampaknya ke omset produksi mencapai 2 miliar di tahun 2019 dan sekarang mendapat lelang dari kementerian pusat terkait pengadaan alat kesenian angklung selalu merucutnya ke Ciamis, sampai memasok ke Jambi, Aceh, dan Sulawesi. Perkembangan ini juga menjadikan adanya kerukunan, pelestarian budaya dan kegiatan rutin untuk masyarakat. Periodisasi perkembangan Kampung Angklung dapat dilihat sebagai berikut:

\section{a. Periode 1992-2000}

Periodisasi perkembangan Kampung Angklung 1992-2000, setelah pindah ke Ciamis angklung banyak diminati, sehingga kebanjiran pesanan padahal saat itu di tahun 1997-1998 Indonesia sedang mengalami krisis moneter global. Namun krisi moneter tidak mengurangi minat masyarakat untuk membeli angklung baik itu dari pegiat seni angklung maupun dari dunia pendidikan. Pada tahun 1999 sampai 2000 Alimudin diundang untuk mewakili Provinsi Jawa Barat dalam Event Pameran se-Asia yang berlokasi di Vietnam. Produk angklung yang dijual pada masa ini dapat dikatakan periode yang menggembirakan dengan omzet yang banyak dan mampu meningkatkan pendapatan masyarakat sekitar. Periode 1992 sampai 2000 jumlah produksi angklung sebanyak 20-30 unit dalam sebulan dengan jumlah pekerja 40 orang. Omzet yang diperoleh sekitar Rp. 30.000.000,- dalam setiap bulan tergantung dari jenis angklung yang dipesan. Dalam 1 tahun penghasilan dari angklung bisa mencapai Rp. 350.000.000,-. Angklung dari kampung angklung dikirim ke daerah-daerah seluruh indonesia, dengan fokus pembeli dari dunia pendidikan.

\section{b. Periode 2000-2010}

Perkembangan Kampung Angklung di tahun 2000-2010 tidak jauh berbeda dengan tahuntahun sebelumnya. Angklung yang berasal dari Kampung Angklung semakin banyak dikenal oleh masyarakat se-Indonesia. Bahkan banyak mendapatkan penghargaan dan peminat serta pegiat seni angklung semakin bertambah. Periode 2000 sampai 2010 jumlah produksi angklung sebanyak 2045 unit dalam sebulan dengan jumlah pekerja 65 orang. Omzet yang diperoleh sekitar Rp. 47.000.000 dalam setiap bulan tergantung dari jenis angklung yang dipesan. Penghasilan angklung dalam 1 tahun bisa mencapai $\mathrm{Rp}$. 500.000.000. Dalam periode ini terjadi pelonjakan pembeli meskipun tidak terlalu banyak peningkatannya. 


\section{Periode $\mathbf{2 0 1 0 - 2 0 2 0}$}

Periode 2010-2015 pembuatan angklung menjadi mayoritas mata pencaharian masyarakat di kampung tersebut. Bahkan di 2016, Alimudin mendapat penghargaan dari Gubernur Jawa Barat Ahmad Heryawan sebagai pelopor pemberdayaan masyarakat. Melihat prospek Kampung Angklung Panyingkiran yang semakin berkembang, ada wacana oleh pemerintah setempat untuk mengajukan Kampung Nempel menjadi salah satu tujuan wisata edukasi yang dibingkai oleh nuansa seni tradisi (Wawancara dengan Alimudin Ketua Adat, tanggal 09 maret 2021). Pada 2017 memutuskan untuk memproduksi dan menjadi pelaku seni sehingga banyaknya undangan dan pesanan angklung dari dunia pendidikan. Pada 2018 mendapatkan kontrak dari GTKI Jabar untuk setiap kabupaten yang ada di Jawa Barat. Hal ini merupakan angin segar bagi kampung angklung, karena mampu meningkatkan kembali pendapatan masyarakat. Pada 2019 mendapatkan penghargaan dari Himpaudi dan menjadi narasumber dalam pengenalan kesenian angklung pada siswa se-Jawa Barat.

Periode 2010-2020 jumlah produksi angklung sebanyak 400 unit dalam 6 bulan dengan jumlah pekerja 137 orang. Proses produksi angklung, saat ini belum memiliki tempat industri yang besar, produksi hanya dilakukan di setiap rumah masing-masing pengrajin angklung. Pembagian pengiriman barang setiap bulan dibagi menjadi dua kali pengiriman ke seluruh TK/PAUD/SD se Jawa Barat. Omzet yang diperoleh sekitar Rp. 59.000.000,- dalam setiap bulan. Omzet pada periode 2010 sampai 2020 setiap tahunnya mencapai Rp. 700.000.000,-- Penghasilan angklung yang diperoleh pada periode 2010 sampai 2020 hampir mencapai sekitar 1 Miliar karena tingginya minat masyarakat dan dunia pendidikan serta pegiat seni terhadap kesenian angklung.

Sisi lainnya berkaitan dengan karakter masyarakat agraris yang humanis. Watak masyarakat agraris yang dikategorikan sebagai masyarakat kolektif yang cenderung memandang kelompok kerja dan organisasi tempat mereka bekerja menjadi bagian yang tak terpisahkan dari diri mereka, sehingga ikatan dengan huma sebagai alat produksi menjadi lebih kuat dan mengakar dalam. Di sisi lain kehidupan agraris merupakan sebuah budaya yang penuh dengan mitos dan tabu. Antropolog sosial, Malinawsky dalam Endraswara (2013) berpendapat bahwa mitos sebagaimana ada dalam suatu masyarakat, bukanlah semata-mata cerita yang dikisahkan, tetapi merupakan kenyataan yang dikhayati. Mitos merupakan daya aktif dalam kehidupan serta tumbuh dalam ideologi masyarakat sehingga akhirnya mampu mempengaruhi sendi kehidupan lainnya.

Mitos dalam masyarakat dapat digambarkan sebagai bentuk apresiasi terhadap alam sebagai bagian dari pola relasi dalam sisi kehidupan masyarakat, dan dengan kekuatan yang menurut mereka turut memberi mereka penghidupan. Mereka gambarkan dalam berbagai macam ritual, upacara dan sesajian. Sehingga dalam hal ini apa yang biasa dilakukan dalam mata pencahariannya, maka di dalam upacara atau ritual akan mereka representasikan, baik dalam bentuk sajian secara utuh maupun hanya bersifat simbolis (Wawancara dengan Alimudin Ketua Adat, tanggal 09 maret 2021). Hubungan mitos dengan alam sangatlah erat, sehingga penghormatan terhadap alam dan kehidupan transeden dalam masyarakat agraris sangat kental. Penghormatan tersebut dalam masyarakat agraris tradisional dimaksudkan agar mereka terhindar dari malapataka dan kemarahan alam atau dari yang mereka percayai memiliki kekuatan sebagai penjaga dalam kehidupannya. Dalam masyarakat tradisional yang kental dengan kehidupan agraris, adanya hubungan antara seni pertunjukan dengan bentuk ritual kepercayaan menjadi hal yang biasa (Soedarsono, 2010).

Dalam kehidupan masyarakat agraris di Jawa Barat telah diketahui bahwa angklung dan dogdog digunakan sebagai sarana ritual untuk menghormati Dewi Sri. Penggunaan bambu yang dipotong pada periode cikal bakal tersebut merupakan representasi dari fungsi angklung, yang dipercaya masyarakat bahwa bambu merupakan salah satu tanaman yang disukai dan tumbuh pada makam Dewi Sri. Oleh karena itu merupakan sebuah hal yang wajar jika dalam masyarakat Kampung Angklung Panyingkiran alat musik angklung dihadirkan dalam ritual ataupun pertunjukkan seni angklung (Wawancara dengan Alimudin Ketua Adat, tanggal 09 maret 2021). 
Dilihat dari sudut pandang seni khususnya seni musik, bahwa musik merupakan gambaran dari alam yang dipresentasikan dalam media bunyi. Seni merupakan produk masyarakatnya adalah benar sepanjang dipahami bahwa karya seni jenis tertentu itu diterima oleh masyarakatnya karena memenuhi fungsi seni dalam masyarakat tersebut. Perkembangan selanjutnya dalam permainan angklung tradisi disertai pula dengan unsur gerak dan ibing (tari) yang ritmis dengan pola dan aturan-aturan tertentu. Pola-pola gerak ini disesuaikan dengan kebutuhan upacara penghormatan padi, misalnya pada waktu mengarak padi ke lumbung (ngampih pare, nginebkeun), juga pada saatsaat mitembeyan, yaitu mengawali menanam padi yang di sebagian tempat di Jawa Barat disebut ngaseuk. Demikian pula pada saat pesta panen dan Seren Taun dipersembahkan permainan Angklung. Terutama pada penyajian angklung yang berkaitan dengan upacara padi, kesenian ini menjadi sebuah pertunjukan yang sifatnya arak-arakan atau helaran, bahkan di sebagian tempat menjadi iring-iringan rengkong dan dongdang serta jampana 'usungan pangan' dan sebagainya.

Angklung yang ada di Kampung Angklung Panyingkiran terdiri dari angklung tradisional sampai dengan angklung modern. Jenis angklung tradisional yang hingga kini masih ada di lingkungan masyarakat yaitu Angklung Buncis. Angklung Buncis merupakan seni pertunjukan yang bersifat hiburan. Pada masa awal kelahirannya, angklung buncis berfungsi sebagai kelengkapan pada penyelenggaraan upacara pertanian. Kendatipun saat ini ritual pertanian masih dilaksanakan oleh masyarakat di lingkungan Kampung Angklung Panyingkiran, akan tetapi dalam penyelenggaraannya telah banyak berubah. Di antara perubahan yang terjadi adalah tidak difungsikannya kesenian Angklung Buncis pada ritual pertanian.

Beberapa kalangan menyebutkan bahwa pada 1990-an dapat dianggap sebagai berakhirnya fungsi ritual Angklung Buncis dalam ritual penghormatan padi, karena sejak itu Angklung Buncis berubah menjadi pertunjukan hiburan. Sejalan dengan itu tempat-tempat penyimpanan padi pun leuit 'lumbung' mulai menghilang dari rumah-rumah penduduk, diganti dengan karung sebagai wadah yang dipandang lebih praktis, dan mudah dibawa ke mana-mana. Padi pun sekarang banyak yang langsung dijual, tidak disimpan di lumbung.

Dengan demikian kesenian Angklung Buncis yang tadinya digunakan untuk acara-acara ngunjal 'membawa padi' tidak diperlukan lagi. Nama Angklung Buncis diambil dari teks sebuah lagu yang terkenal di kalangan masyarakat Sunda, yaitu "cis kacang buncis nyengcle...", dst. Teks tersebut terdapat dalam lagu yang biasa dibawakan dengan iringan kesenian Angklung Buncis, sehingga kesenian ini pun kemudian dinamakan Angklung Buncis. Instrumen yang digunakan dalam kesenian Angklung Buncis adalah: 2 angklung indung, 2 angklung ambrug, angklung panempas, 2 angklung pancer, 1 angklung enclok, 3 buah dogdog yang terdiri dari 1 talingtit, panembal, dan badublag. Dalam perkembangannya kemudian ditambah dengan tarompet, kecrek, dan goong. Selain jenis-jenis angklung tradisional di atas, masih ada beberapa jenis angklung tradisional (Wawancara dengan Alimudin Ketua Adat, tanggal 09 maret 2021).

Di kalangan masyarakat Sunda zaman dulu, angklung sudah dikenal sebagai alat musik tradisional yang tidak semata-mata sebagai media hiburan, melainkan juga memiliki fungsi penting dalam ritual adat seputar pertanian. Pada perkembangan berikutnya, keberadaan kesenian angklung mengalami pasang surut, bahkan sempat mengalami penurunan yang sangat drastis. Pada waktu itu, alat kesenian angklung tidak lagi dimainkan sebagai peralatan seni hiburan maupun seni sakral, melainkan dipergunakan oleh para pengemis untuk mengamen dari rumah ke rumah.

Kemajuan di bidang pendidikan telah membawa perubahan yang sangat besar pada perkembangan dunia seni. Pendidikan telah mampu membuka dan memperluas cakrawala berpikir, serta menumbuhkan daya kreativitas dan inovasi. Demikian yang terjadi pada kesenian angklung. Kesenian Angklung yang semula hanya merupakan kesenian tradisional dengan nada dan irama serta penampilan yang sangat sederhana, berkat kreativitas seorang seniman besar, kini angklung telah berubah menjadi kesenian modern yang telah mendunia.

Angklung modern bernada diatonis menjadi pentatonis. Atau dengan kata lain mengubah tangga nada angklung dari angklung tradisional yang bertangga nada pentatonik (da, mi, na, ti, la) 
menjadi angklung modern dengan tangga nada diatonik chromatik (do,di,re,ri,mi, fa,fi,sol, sel,la,li,ti,do). Angklung modern yang ada di Kampung Angklung Panyingkiran terinspirasi dari idenya Bapak Daeng (master angklung yang ada di Indonesia). Idenya ini muncul didorong oleh keprihatinannya melihat anak-anak didiknya yang kebanyakan kurang berminat belajar musik dan seni vokal. Keinginan Daeng untuk bisa memperoleh alat musik yang murah dan sederhana pun mulai mendapat jalan, ketika pada suatu hari di depan rumahnya ada seorang pengamen tua memainkan alat musik angklung. Daeng sangat terkesan dengan bunyi angklung yang dimainkan oleh pengamen tua itu, yang membawakan lagu Sunda "Cis kacang buncis...". Lagu itu dalam tangga nada pentatonis yang sudah cukup akrab di telinga Daeng. Tetapi yang membuatnya terkesan bukan lagunya, melainkan alat musik angklungnya. la terinspirasi untuk mengubah alat musik angklung yang dimainkan oleh pengamen itu, yang bertangga nada pentatonis, menjadi angklung yang bernada diatonis chromatis. la pun kemudian membeli angklung milik pengamen itu untuk dipelajarinya (Wawancara dengan Alimudin Ketua adat, tanggal 09 maret 2021).

Demikianlah, angklung yang merupakan kesenian khas Indonesia berasal dari pengembangan angklung Sunda. Pada awal kelahirannya, angklung Sunda memiliki tangga nada pentatonis yang bernada lima (salendro atau pelog) oleh Daeng Sutigna diubah nadanya menjadi tangga nada Barat (solmisasi) sehingga dapat memainkan berbagai lagu lainnya. Hasil pengembangannya kemudian diajarkan kepada siswa-siswa sekolah (Wawancara dengan Alimudin Ketua Adat, tanggal 09 maret 2021).

\section{KESIMPULAN}

Awal kemunculan Kampung Angklung Panyingkiran Ciamis, tak lain berkat kiprah seorang pengrajin angklung bernama Alimudin yang akrab disapa Mumu Angklung sekitar tahun 1990-an yang membuat dan menjual angklung. Pada 1992 sampai 2000 Kampung Angklung memiliki nama Sanggar Angklung Panji Mekar. Namun seiring perkembangan zaman, masyarakat mengaitkannya dengan Saung Angklung Udjo, dan akhirnya nama tersebut diubah menjadi Kampung Angklung. Angklung mulai dilirik pasar domestik dan pesanan semakin meningkat. Sehingga beliau mengajak masyarakat setempat untuk bersama-sama memproduksi angklung. Kemudian beliau berinisiatif mendirikan daerahnya menjadi kampung angklung panyingkiran. Impiannya terwujud pada 2014 dengan diresmikannya dan diakuinya Kampung Angklung Panyingkiran setelah mengajukan kepada Pemkab Ciamis. Kampung Angklung Panyingkiran semakin banyak dikenal masyarakat seIndonesia, dengan semakin bertambahnya peminat dan pegiat seni angklung. Dimulai tahun 2010 sampai 2020, angklung menjadi mayoritas mata pencaharian masyarakat di kampung tersebut. Pada 2017 memutuskan untuk memproduksi serta menjadi pelaku seni sehingga banyaknya undangan dan pesanan angklung terutama dari dunia pendidikan. Pada 2018 mendapatkan kontrak dari GTKI Jabar. Dan tahun 2019 Kampung Angklung Panyingkiran mendapatkan penghargaan dari HIMPAUDI dan menjadi narasumber dalam pengenalan kesenian angklung pada siswa se-Jawa Barat.

\section{REKOMENDASI}

Berdasarkan hasil penelitian Sejarah Berdirinya Kampung Angklung Dan Perkembangannya Di Desa Panyingkiran Kecamatan Ciamis Kabupaten Ciamis Tahun 1992-2020. Maka penulis merekomendasikan bahwa perlu dilakukan sosialisasi ke masyarakat lebih luas untuk meningkatkan kesadaran dan rasa memiliki dalam upaya meningkatkan minat masyarakat terhadap kesenian Angklung, baik melalui jalur pendidikan formal-non formal maupun sanggar-sanggar kesenian. Disamping itu, perlu dilakukan kajian yang mendalam mengenai keberadaan kesenian Angklung di lingkungan masyarakat dalam perspektif sejarah, dan diperlukan kepedulian dari semua pihak, baik itu aparat pemerintah, para pemerhati budaya maupun lapisan masyarakat untuk terus menggali potensi wilayah yang dapat mendukung peningkatan perekonomian masyarakat. 


\section{UCAPAN TERIMAKASIH}

Ucapan terimakasih penulis tujukan kepada masyarakat Kampung Angklung Panyingkiran dan pihak-pihak yang telah membantu dalam penelitian ini.

\section{DAFTAR PUSTAKA}

Alimudin. (2021, 9 Maret 2021). Ketua Kampung Angklung.

Brata, R. Y., \& Wijayanti, Y. (2020). Dinamika Budaya Dan Sosial Dalam Peradaban Masyarakat Sunda Dilihat Dari Perspektif Sejarah. Jurnal Artefak Vol.7 No.1 April 2020.

Budi, D. (2001). Angklung Baduy Dalam Upacara Ritual Ngaseuk. Tesis Tidak Di Publikasikan. Program Pasca Sarjana seni Pertunjukan. Juirusan IImu-IImu Humaniora. Universitas Gajah Mada.

Dhea. (9 Maret 2021). Ketua Kesenian.

Gottschalk, L. (1975). Mengerti Sejarah (Pengantar Metode Sejarah), Terjemahan. Nugroho Notosutanto. Jakarta: Universitas Indonesia.

Ikin. (2021, 10 Maret 2021). Ketua Pengrajin Angklung.

Ismaun. (2005). Sejarah Sebagai Ilmu. Bandung: Historia Utama Press.

Koentjaraningrat. (2000). Pengantar IImu Antropologi. Jakarta: Rineka Cipta.

Kuntowijoyo. (1995). Pengantar IImu Sejarah. Yogyakarta: Bentang Budaya. . (2013). Pengantar Ilmu Sejarah. Yogyakarta: Tiara Wacana.

Kusmaya, A. (2014). Perkembangan Dan Sistem Pewarisan Kesenian Angklung Badud Di Cijulang Pangandaran. Skripsi di Publikasikan. Jurusan Pendidikan Seni Musik Fakultas Bahasa dan Seni. Universitas Negeri Yogyakarta.

Mimi. (2021, 10 Maret 2021).Tokoh Masyarakat Kampung Angklung.

Moelong, L. J. (2011). Metode Penelitian Kualitatif Edisi Revisi. Bandung: PT.

Pajriah, S. (2018). Peran Sumber Daya Manusia Dalam Pengembangan Pariwisata Budaya Di Kabupaten Ciamis. Jurnal Artefak e-ISSN: 2580-0027.

Ratih, D., \& Suryana, A. (2020). Nilai-Nilai Kearifan Lokal Leuweung Gede Kampung Kuta Ciamis Dalam Mengembangkan Green Bihavior Untuk Meningkatkan Karakter Mahasiswa. Jurnal Artefak Vol.7 No.2 September 2020.

Ranjabar, J. (2006). Sistem Sosial Budaya Indonesia : Suatu Pengantar. Bogor : PT. Ghalia Indonesia.

Rosyadi. (2012). Angklung dari Angklung Tradisional ke Angklung Modern. Jurnal Patanjala Vol.4, No. 1, Maret 2012 Balai Pelestarian Sejarah dan Nilai Tradisional Bandung. 
Sjamsuddin, H. (2007). Metodologi Sejarah. Yogyakarta: Penerbit Ombak. . (2012). Metodologi Sejarah. Yogyakarta: Penerbit Ombak.

Soedarsono. (2010). Seni Pertunjukan di Era Globalisasi. Yogyakarta: Gajah Mada University Press.

Soepandi, A. (1975). Dasar-Dasar Karawitan. Bandung. Lembaga Kesenian Bandung.

Sriningsih, Y., Soedarmo, U. R., \& Kusmayadi, Y. (2021). Kesenian Genjring Ronyok Sebagai Sumber Belajar Sejarah Lokal di SMA Negeri 1 Kawali Kelas X Tahun Ajaran 2019-2020. JKIP (Jurnal Keguruan dan IImu Pendidikan), 2 (1), 115-122.

Sugiyono. (2015). Metode Penelitian Kombinasi. Bandung: Alfabeta.

(2017). Metode Penelitian Pendidikan Pendekatan Kuantitatif, Kualitatif, dan R\&D. Bandung: CV. Alfabeta.

Widyasari, A, (2018). Jedor Sebagai Media Penyebaran Agama Islam Tulungagung. Tulungagung. Jurusan Aqidah dan Filsafat Islam Fakultas Ushuluddin Adab dan Dakwah, IAIN Tulungagung. Skripsi. Tidak diterbitkan. 